\title{
Impact of Front Line Demonstrations on Mustard Productivity in Hanumangarh District of Rajasthan, India
}

\author{
Akshaya Ghintala*, Bheiru Singh and Mukesh Kumar Verma \\ Krishi Vigyan Kendra, Nohar, Hanumangarh-II (Raj.), India \\ *Corresponding author
}

\begin{tabular}{|l|}
\hline K e y w o r d s \\
Frontline demonstrations, \\
Extension gap, \\
Technology gap, \\
$\begin{array}{l}\text { Technology index, } \\
\text { Mustard \& transfer of } \\
\text { technology }\end{array}$ \\
\hline Article Info \\
\hline Accepted: \\
12 August 2018 \\
Available Online: \\
10 September 2018 \\
\hline
\end{tabular}

A B S T R A C T
Mustard is one of the most important oilseed crops of the country. The development of the Agriculture is primarily depends on the application of the scientific technologies by making the best use of available resources. The Present study was carried out at Hanumangarh district of North Rajasthan during the year 2016-17. To increase the production, productivity and quality of agricultural produce, Front Line Demonstrations are being conducted at various farmers' field. All the recommended Practices were provided to the selected farmers. The data related to the cost of cultivation, production, productivity, gross return and net return were collected as per schedule and analyzed. Result of the present study revealed that the high yielding variety of Mustard RH-749 recorded the higher yield $(1450 \mathrm{~kg} / \mathrm{ha})$ as compared to local check $(1220 \mathrm{~kg} / \mathrm{ha})$ traditionally grown by the farmers. The percentage increase in the yield over local check $18.85 \%$ was recorded. The technology gaps in terms of productivity $(750 \mathrm{~kg} / \mathrm{ha})$ were calculated. The technology index values $34.09 \%$ was recorded. The result of the study indicated the gap existed in the potential yield and demonstration yield is due to soil fertility and weather conditions. By conducting front line demonstration (FLDs) of proven technologies, yield potential of Mustard can be increased up-to great extent. This will substantially increase the income as well as the livelihood of the farming community.

\section{Introduction}

Mustard (Brassica juncea L.) is an important Rabi season oilseed crop; belongs to family Cruciferae and genus Brassica. Mustard seed is the world's second leading source of vegetable oil, after soybean. It is also the second most leading source of protein meal in the world after soybean. It is mainly grown in northern part of India, Rajasthan is the largest producing state followed by Uttar Pradesh. Mustard crop required lower water requirement $(240-400 \mathrm{~mm})$ for completing life cycle, therefore it is fits well for rain fed cropping system. Mustard seed contains average $34-43 \%$ oil content and contributes for $32 \%$ of total edible oil. The total production of this crop in India is $8.08 \mathrm{~m}$ tones with a productivity of $1420 \mathrm{~kg} / \mathrm{ha}$. In Rajasthan, rapeseed and mustard occupies prime place amongst all the oilseed crops grown in the state, occupying $6.5 \mathrm{~m}$. hectares area, with production of $3.5 \mathrm{~m}$ tones and 1208 $\mathrm{kg} / \mathrm{ha}$ average yield Sodani et al., (2017).

Frontline demonstration may play a very 
important role in proper transfer of technologies and changing scientific temperament of the famers. Frontline demonstration is the new concept of field demonstration evolved by the ICAR with the inception of the technology mission on oilseed crops during mid-eighties.

The main objective of frontline demonstrations is to demonstrate newly released crop production and protection technologies and its management practices in the farmers filed under different agro-climatic regions and farming situations. Frontline demonstrations are conducted in a block of two or four hectare land in order to have better impact of the demonstrated technologies on the farmers and field level extension functionaries. The agricultural technology is not generally accepted by the farmers completely in all respects.

As such there always appears to be a gap between the recommended technology by the scientist and it's modified from at the farmer's level. The technology gap is thus the major problem in the efforts of increasing agricultural production in the country.

A need of the day is to reduce the technological gap between the agricultural technology recommended by the scientist and its acceptance by the farmers on their field.

In view of the above factors, frontline demonstrations were undertaken in a systematic manner on farmer's field to show the worth of a new variety and convince the farmers to adopt improved cultivation practices of Mustard for increasing productivity of Mustard. Keeping in view the present investigation attempts to study the yield gap between frontline demonstration trails and farmers yield, extend of technology adoption and benefit cost ratio.

\section{Materials and Methods}

The study was conducted in Hanumangarh district of Rajasthan during the year 2016-17. The data on output of high yield variety of Mustard crop and inputs used per hectare have been collected from the frontline demonstration trails conducted by KVK. All the participating farmers were trained on various aspects of Mustard production technologies. Recommended agronomic practices and genuine seeds of Mustard were used for frontline demonstrations in 0.5 hectare area per demonstration. A one fifth area was also devoted to grow local standard check. The frontline demonstrations were conducted by KVK from Rabi 2016-2017 in area of 4 hectare on 10 locations (farmers).

Thus, a total of 10 full package frontline demonstrations were selected. The data collected from the reports of frontline demonstrations conducted by the KVK on the production technology of Mustard crop were used. These were compared with prevailing production technologies of Mustard crop (which were taken in check plots).The performances of improved varieties with improved technologies evaluated closely by the organizing seasonal training, method of demonstrations, field days and by taking cropcut experiments. Regular diagnostic visit by the scientists helped in proper execution of demonstration as well as collection of farmer's opinion about the demonstration field. Production and economic data for frontline demonstrations and local practice were collected and analyzed.

In the present study, technology index was operationally defined as the technical feasibility obtained due to implementation of frontline demonstration in Mustard. To estimate the technology gap, extension gap and technology index following formulae used by Samuei et al., (2000) have been used: 
Extension Gap $(\mathrm{kg} / \mathrm{ha})=$ Demonstration yield Farmer practices yield (Local check)

Technology Gap (kg/ha) =Potential yield Demonstration yield

Technology Index = Potential yieldDemonstration yield/Potential yield X 100

\section{Results and Discussion}

\section{Performance of frontline demonstration}

A Comparison of productivity levels between demonstrated variety and local checks is shown in Table 1. During the period under study, it was observed that in frontline demonstrations, the improved Mustard variety RH-749 recorded the higher seed yield (1450 $\mathrm{kg} / \mathrm{ha}$ ) when compared to local check (1220 $\mathrm{kg} / \mathrm{ha}$ ). The percentage increase in the yield over local check was $18.85 \%$. More and less similar yield enhancement in different crops in frontline demonstration had apply been documented by Surywaanshi and Prakash (1993), Hiremath et al., (2007), Mishra et al., (2009), Dhaka et al., (2010), Kumar et al., (2010) and Singh (2015).
From these results it is evident that the performance of improved variety was found better than the local check under same environment conditions. Farmers were motivated by results of agro technologies applied in the frontline demonstrations trails and it is expected that they would adopt these technologies in the coming years. Yield of the frontline demonstration trails and potential yield of the crop was compared to estimate the yield gaps which were further categorized into technology index.

\section{Technology gap}

The technology gap shows the gap in the demonstration yield over potential yield and it was $750 \mathrm{~kg}$ per hectare. The frontline demonstrations were laid down under the supervision of KVK Scientist at the farmer's field.

There exists a gap between the potential yield and demonstration yield. This may be due the weather conditions. Hence, location specific recommendations are necessary to bridge the gap. These findings are similar to the findings of Patel et al., (2013).

Table.1 Yield, technology gap and technology index of demonstration

\begin{tabular}{|l|c|c|c|c|}
\hline Variables & Yield (kg/ha) & $\begin{array}{l}\text { Increase (\%) over } \\
\text { Local Check }\end{array}$ & $\begin{array}{l}\text { Technology } \\
\text { Gap (kg/ha) }\end{array}$ & $\begin{array}{l}\text { Technology } \\
\text { Index }(\%)\end{array}$ \\
\hline Local check & 1220 & - & - & - \\
\hline Demonstration (RH-749) & 1450 & 18.85 & 750 & 34.09 \\
\hline
\end{tabular}

Table.2 Economic of frontline demonstration

\begin{tabular}{|l|c|c|c|c|}
\hline Variables & $\begin{array}{l}\text { Cost of } \\
\text { cultivation }\end{array}$ & $\begin{array}{l}\text { Gross return } \\
\text { (Rs//ha) }\end{array}$ & $\begin{array}{l}\text { Net return } \\
\text { (Rs/ha) }\end{array}$ & $\begin{array}{l}\text { Benefit: Cost } \\
\text { ratio }\end{array}$ \\
\hline Local check & 13000 & 43920 & 30920 & 3.38 \\
\hline Demonstration (RH-749) & 14000 & 52200 & 38200 & 3.73 \\
\hline Additional in demonstration & 1000 & 8280 & 7280 & $8.28^{*}$ \\
\hline
\end{tabular}

* Incremental Benefit cost ratio 


\section{Technology index}

Technology Index shows the feasibility of the variety at the farmer's field. The lower the value of the technology index more is the feasibility. Results of the study depicted in Table 1 revealed that the technology index value was $34.09 \%$. The results of the present study are in consonance with the findings of Singh et al., (2007), Patel et al., (2013) and Singh (2015).

\section{Economic of frontline demonstration}

The economics of Mustard production under frontline demonstrations were estimated and the results of the study have been presented in Table 2. The results of economic analysis of Mustard production revealed that frontline demonstrations recorded higher gross return Rs.52200 per ha and net return Rs.38200 per ha with higher benefit cost ratio (3.73) as compared to local checks. These results are in accordance with the finding of Hirenmath et al., (2007) and Hirenmath and Nagaraju (2009). Further, additional cost of Rs.1000 per ha in demonstration has increased additional net returns Rs.8280 per ha with incremental benefit cost ratio 8.28 suggesting it's higher profitability and economic viability of the demonstration. More and less similar results were also reported by Hirenmath et al., (2007) Dhaka et al., (2010) and Patel et al., (2013).

The finding of the study revealed that wide gap existed in potential and demonstration yield in high yield Mustard varieties due to technology and extension gap in Hanumangarh district of Rajasthan. By conducting frontline demonstration was an effective tool for increasing the productivity of Mustard crop. Improved technologies in frontline demonstrations enhanced yield and increase percent over the farmers practice in local check plots. This will substantially increase the income as well as the livelihood of the farming community.

This created greater curiosity and motivation among other farmers who do not adopt improved practices of Mustard cultivation. The demonstrations also built the relationship and confidence between farmers and scientist of KVK.

The study emphasizes the needs to educate the farmers in adoption of improved technology to narrow the extension gaps through various technology transfer centers. Therefore it is suggested that these factors may be taken for considered to increase the scientific temperament of the farmers.

\section{References}

Anonymous (2013-2014). "Vision 2020 Perspective plan". NRCRM, Bharatpur.

Dhaka, B. L., Meena, B. S. and Suwalka, R. L. (2010). "Popularization of Improved Maize production technology through frontline demonstrations in southeastern Rajasthan". Journal of Agri. Sci., 1(1):39-42.

Hiremath, S. M. and Nagaraju, M. V. (2009). "Evaluation of frontline demonstration trails on onion in Haveri district of Karnataka". Karnataka j. of agric. Sci., 22(5): 1092-1093.

Hiremath, S. M., Nagaraju, M. V. and Shashidhar, K. K. (2007). "Impact of frontline demonstration on onion productivity in farmers field". Nation. Sem. Appropriate Extn. Strat. Manag. Rural Resources, Univ. agric. Sci. Dharward. December 18-20:100.

Kumar, A., Kumar, R., Yadav, V.P.S. and Kumar, R. (2010). "Impact Assessment of Frontline Demonstrations of Bajara in Haryana State. Indian Res. J. Ext. Edu. 10 (1): 105-108. 
Mishra, D.K., Paliwal, D.K., Tailor, R.S. and Deshwal A.K. (2009). "Impact of Front line Demonstrations on yield enhancement of Potato". Indian Res. J. Ext. Edu. 9(3)26-28.

Patel, M. M., Jhajharia, A. K., Khadda, B. S. and Patil, L. M. (2013). "Frontline demonstration: An effective communication approach for dissemination of sustainable cotton production technology". Ind. J. Extn. Edu. \& R.D., 21: 60-62.

Samuei, S. K., Miha, S., Roy, D. K., Mandal, A. K. and Saha, D. (2000). "Evaluation of Frontline demonstration on groundnut". Journal of Indian Society Coastal Agril. Res., 18:180-183.

Sharma, R. N. and Sharma, K. C. (2004). "Evaluation of frontline demonstration trails on oilseeds in Baran district of Rajasthan". Madhya Pradesh Journal of Extn. Edu., 7: 94-95.

Singh, D. (2015). "Impact of front line demonstrations on productivity of Carrot in Dholpur district of Eastern
Rajasthan". Ind. J. Extn. Edu. \& R.D., 7(2\&3):94-95

Singh, D. K. Gautam, U. S. and Singh R. K. (2007). "Study on yield gap and level of demonstrated crop production technology in Sagar district". Ind. Res. J. Extn. Edu., 7(2\&3):94-95

Singh, P.; Sharma, K. C.; Chaturvedi, D. (2014). "Knowledge and adoption level of Mustard technology in western Rajasthan". Ind. J. Extn. Edu. \& R.D., 22: 203-206.

Sodani R., Seema, Singhal R.K., Gupta S., Gupta N., Chauhan K.S. and Chauhan J. (2017) "Performance of yield and yield attributes of ten Indian Mustard (Brassica juncea L.) Genotypes under drought stress". Int. J. Pure App. Biosci. 5 (3): 467-476.

Suryawanshi, S.D. and Prakash, M. 1993. "Impact of viable technology of promoting oil seeds". Maharastra Indian Journal of Agricultural Economics 48: 420. 94-95.

\section{How to cite this article:}

Akshaya Ghintala, Bheiru Singh and Mukesh Kumar Verma. 2018. Impact of Front Line Demonstrations on Mustard Productivity in Hanumangarh District of Rajasthan, India. Int.J.Curr.Microbiol.App.Sci. 7(09): 1942-1946. doi: https://doi.org/10.20546/ijcmas.2018.709.236 